\title{
Przechadzki
}

\section{Babcia z Zabierzowa. Przekład z lokalnego na lokalny}

Leonard Neuger

TEKSTY DRUGIE 2017, NR 1, S. 432-439

DOI: $10.18318 /$ td.2017.1.34

ęzyk ojczysty traktowany jest przez użytkowników jako język obsługujący cały świat. To prawda, ale ten „cały świat" musi się mieścić w tym danym nam języku. $\mathrm{Na}-$ wet otwarcie na światowość jest tu lokalne, ponieważ jest ono zawsze perspektywiczne. Nasza światowość nie musi zawsze pokrywać się ze światowością innych języków. Nasza oczywistość nie jest oczywistością uniwersalną. Identycznie ma się rzecz z językiem oryginału. W ramach tego języka powstaje lokalny idiom poety. A idiom ten budowany jest na specyficznie lokalnej kulturze kraju. Inaczej rzecz się ma z „my” Szymborskiej, tutaj mamy do czynienia z uniwersalizmem. Najlepiej wyraził to Czesław Miłosz: „In Szymborska's poetry «we» denotes all of us of this planet now, joined by a common consciousness, a «post-consciousness», post-Copernican, post-Newtonian, post-Darwinian, post-two-World-Wars, postcrimes-and-invensions-of-the-twientieth-century"1. Duża część twórczości Wisławy Szymborskiej powstała

1 Cz. Milosz Foreword, w: Wisława Szymborska, Miracle Fair, Selected Poems of Wisława Szymborska, Winner of the Nobel Prize, trans. by J. Trzeciak, W. W. Norton \& Company, New York-London 2001, s. 1.

Leonard Neuger Ukończył polonistykę na UJ. W latach 1974-1982 pracował na UŚ, a od 1983 do 2012 w Instytucie Slawistyki Uniwersytetu Sztokholmskiego (2000 profesura, 2003-2007 dyrektor Instytutu). Przetłumaczył m.in. książkę M.S.C. Schuback, Pochwała nicości. Eseje o hermeneutyce filozoficznej (2008). Autor książek: Z perspektywy tłumacza: szkice o poezji szwedzkiej (1997), Pomysły do interpretacji: studia i szkice o literaturze polskiej (1997), Ćwiczenia z wrażliwości: duże i małe szkice literackie (2006). 
w PRL-u, do niego się odnosiła zarówno w sferze realiów, idiomu konwersacyjnego, jak i zjawisk społecznych. Zwracam na to uwagę, ponieważ PRL przeszedł już do historii i coraz pilniejsza wydaje się potrzeba opatrzenia jej wierszy, także w Polsce, przypisami i komentarzami, co zresztą znamionuje gest tłumacza: Jeśli kategorię translacji potraktujemy dosłownie, jako prze-kładanie (z miejsca na miejsce) to jest ono samo w sobie sygnałem, że „to wszystko" odbywa się "gdzie indziej”, nie tu, u nas, tylko tam. Bywają poeci, gdzie owo "tam” jest od "tu” na tyle daleko, że przepaść między nimi trzeba zapisywać ogromnymi przypisami i komentarzami. Niech przypisy Nabokowa do angielskiego przekładu Eugeniusza Oniegina wystarczą za dowód ${ }^{2}$. Szymborska do takich poetów nie należy: mieści się na ogół w obszarze wiedzy jako tako oczytanego czytelnika. Prawda, oczytanie dzisiejsze różni się coraz bardziej od tego sprzed 5o. lat, ale nie sądzę, żeby tłumacz odczuwał nieodparty imperatyw objaśnienia, kim był Johannes Vermeer. Ale już w wierszu Rzeczywistość wymaga z Końca i początku pojawiają się przejawy życia pod Kannami, Borodino, Kosowym Polem, Guernicą, Jerychem, Białą Górą, Pearl Harbor, Hastings, Cheroneą, Verdun, Akcjum, Hiroszimą. Pojawiają się wreszcie Maciejowice ${ }^{3}$. Oczywiście, tylko Maciejowice przynależą do historii lokalnej, polskiej, ale na miejscu tłumacza czy wydawcy dałbym na wszelki wypadek krótkie objaśnienia, do czego odwołują się te wymienione miejsca, mimo że niemal każdy czytelnik może sobie momentalnie, nie ruszając się z miejsca, znaleźć w wyszukiwarce każde z nich ${ }^{4}$. Paradoksalnie, wiersz Szymborskiej jest właśnie elegią o pobojowiskach historycznych „jeszcze pamiętanych/już zapominanych" (s. 294-295), ale też o życiu, które uparcie stara się wypierać miejsca hekatomb. Jest to zresztą szczególna sytuacja tłumacza, któremu nie wystarczy intuicja, zresztą trafna, że Szymborska wskazuje na

2 Vladimir Nabokov wydał swoje tłumaczenie Eugeniusza Oniegina na angielski w 1964 roku w 4 tomach, gdzie tom pierwszy zawiera wstęp tłumacza i przekład, tom drugi i trzeci - szczegółowe uwagi i komentarze tłumacza, a czwarty - faksymile wydania rosyjskiego z 1837 roku. A. Pushkin Eugene Onegin novel in verse. Translated from Russian with commentary by Vladimir Nabokov, London 1964.

3 Rzeczywistość wymaga z tomu Koniec i początek (1993), wszystkie odwołania do polskich wydań poezji Wisławy Szymborskiej: W. Szymborska Wiersze wybrane, a5, Kraków 2004. (Wiersz Rzeczywistość wymaga - s. 294-295). Dalej będę oznaczał tę książkę skrótem WW z podaniem tytułu wiersza i numeru strony.

4 Taką właśnie strategię objaśnień zastosowała Joanna Trzeciak. Wisława Szymborska, Miracle Fair, Selected Poems of Wisława Szymborska..., Reality Demands: s. 53-54, objaśnienia: s. 145-146. Dalej będę oznaczał tę książkę skrótem JT z podaniem tytułu wiersza i numeru strony. 
miejsca utrwalone w historii, na ogół Europy, i że są to miejsca przełomowych klęsk. Tłumacz musi uplasować te klęski w konkretnym czasie i sytuacji, no i w swoim języku, ponieważ często nazwy własne miejscowości różnią się ortografią, a w polszczyźnie dochodzą do tego zniekształcenia wskutek fleksji i obyczaju językowego. Za przykład niech służą nazwy własne z sufiksem -us, który w polszczyźnie zawsze przybiera formę -usz. Jest więc Juliusz Cezar, Celsjusz i Galileusz. Tłumacząc wiersze wybitnego szwedzkiego romantyka, Erika Johana Stagneliusa ${ }^{5}$, wiedziałem, że nazwisk nie powinno się zmieniać, ale także, że pochodzący z łaciny sufiks -us musi się w polszczyźnie zmienić w -usz. Tyle że obu imperatywów naraz pogodzić się nie da. Ostatecznie zdecydowałem się nie zmieniać brzmienia nazwiska poety. Bitwa pod Akcjum (Actium), chronicznie przez polszczyznę zawłaszczana, w innych językach zachowuje swoją łacińską pisownię. Na nazwę Maciejowice nie ma rady: to polska klęska i nie pozostaje nic innego, jak przypis. Zresztą nazwa jest trudna i nie zawsze nadaje się do wymówienia przez cudzoziemców.

Nie zawsze tak jednak jest. Na przykład w wierszu Rozpoczęta opowieść z tomu Ludzie na moście (1986) ${ }^{6}$, gdzie pojawia się będąca tytułem mojego wystąpienia „babcia z Zabierzowa”. Dokładny cytat brzmi: „zawezwijcie depeszą babcię z Zabierzowa". Jeśli w przytoczonym wierszu Rzeczywistość wymaga porządek nadają nazwy własne miejsc klęsk druzgocących dotychczasowe status quo, to Rozpoczęta opowieść wymienia zasadnicze powody, dla których urodzenie dziecka powinno być odroczone. Pojawiają się tam nazwy własne na wpół mitologiczne, jak Winlandia, ale też odwołania do znanych z historii różnych kultur sytuacji braku stabilności, represji, a nawet hekatomb (aluzja do ucieczki kanałami podczas powstania warszawskiego). Od początku wiersza wiemy, że sytuacja, kiedy narodziny dziecka będą w pełni uzasadnione, nie jest możliwa. Stąd momentowi narodzin (u Szymborskiej - wbrew czy na przekór okolicznościom) towarzyszą gesty magiczne, odwołujące się do różnych kultur, jak choćby rozwiązywanie węzłów na rzemieniach jurty. Wreszcie, $w$ takim kontekście, przywołana zostaje babcia z Zabierzowa. I natychmiast stawia przed tłumaczami poważne problemy. Zabierzów jest położonym blisko Krakowa miasteczkiem, niewyróżniającym się niczym szczególnym, może poza tym, że w związku z powojennymi migracjami jest dość prawdopodobne, że ktoś przenosząc się do Krakowa, tam właśnie zostawił babcię. Oczywiście tylko jeśli przyjmiemy perspektywę Krakowa

5 E. Johan Stagnelius (1783-1823) Elegie, przeł. L. Neuger, Oficyna Literacka, Kraków 1991.

6 W. Szymborska Rozpoczęta opowieść z tomu Ludzie na moście (1986), w: tejże Wiersze wybrane, S. $273-274$. 
jako centrum, co nie wydaje się naciągane w przypadku twórczości poetki przez całe prawie życie z Krakowem związanej. Nie jest to jednak, jak widać, interpretacja zniewalająca. Równie możliwe jest, że Szymborska sięgnęła po pierwszą lepszą nazwę podmiejską. Barańczak i Cavanagh7 Zabierzów lojalnie w swoim przekładzie zostawiają, narażając jednak czytelników na potworne męki przy wymawianiu tej nazwy własnej, zwłaszcza głoski o notacji „rz", która u osób wrażliwych może spowodować pilną wizytę u laryngologa. Inaczej postąpił Anders Bodegård, szwedzki tłumacz poetki. Jedno rozwiązanie, czyli przeniesienie zdarzenia do Szwecji, gdzie także na peryferiach miast znajduje się spory zapas potencjalnych babć, odrzucił (jak wszyscy tłumacze tego wiersza), a to nie z uwagi na babcię, tylko z uwagi na Szymborską. Jeśli bowiem cokolwiek z interpretacji łączącej Zabierzów z Krakowem, jako centrum u Wisławy Szymborskiej wynika, to to, że należy brać pod uwagę lokalizację samego autora. Dla polskiego czytelnika (też zresztą mieszkającego w pobliżu Krakowa) szereg: Szymborska Kraków - Zabierzów jest oczywisty. Rzecz w tym, że dla czytelnika-cudzoziemca jest w gruncie rzeczy podobnie: Szymborska ulokowana jest w Polsce i telegram do babci - wymyślam! - w Oxelösund natychmiast pachnie oszustwem tłumacza. Bo nikt nie uwierzy, że Szymborska w ogóle o takiej miejscowości słyszała, nie mówiąc już o szansie na poprawną wymowę tej nazwy! Przekład, jak widać, jest szczególnym rodzajem literackim, zaznaczającym już na stronie tytułowej książki swoją odrębność.

Skoro przeniesienie Zabierzowa do Szwecji czy też, ujmijmy to szerzej: za granicę, odpadło, to została do dyspozycji tłumacza wielotysięczna gromada polskich miasteczek o nazwach nadających się do wymówienia, że o wsiach nie wspomnę. Czyli misja w swoim woluntaryzmie niewykonalna. Bodegård zadzwonił więc do Szymborskiej i... znalazło się rozwiązanie, przyznaję, bardzo zaskakujące, ale pozbawione przeklętego „rz”. Szymborska zaproponowała Kórnik, łatwiejsze do wymówienia miejsce, gdzie przyszła na świat. I tak jest w tłumaczeniu szwedzkim, i tylko tam ${ }^{8}$, Wisława Szymborska występuje w szczególnej roli: magicznej babci, opiekunki noworodków i ich rodziców w czasach marnych.

7 W. Szymborska A Tale Began, w: Poems New and Collected 1957-1997, trans. by S. Barańczak, C. Cavanagh, Chatham, Kent 1998, s.210-211. Dalej będę oznaczał tę książkę skrótem B\&C z podaniem tytułu wiersza i numeru strony.

8 W. Szymborska En påbörjad berättelse, w: Utopia, Urval och översättning av A. Bodegård, Falköping 1989, s. 116-117. Dalej będę oznaczał tę książkę skrótem AB z podaniem tytułu wiersza i numeru strony. 
Uporawszy się z Zabierzowem, wcale nie uwolniliśmy zawezwania babci od problemów translatorskich. Już sama babcia wpisuje sytuację w pewien nieco już archaiczny gest, mianowicie w czasy, kiedy babcie nie miały wiele do roboty, korzystano z ich pomocy, a więzy rodzinne były bliskie nie tylko w wielkie święta kościelne. W społeczeństwie o rodowodzie chłopskim, jak w Polsce, wobec Holokaustu, ogromnych strat ludzkich w czasie wojny, wielkich powojennych migracji, przemian społecznych, ustrojowych itp. na długi czas zostały zakonserwowane przedwojenne i wojenne relacje rodzinne, niekoniecznie idylliczne.

Na przykład we frazie: „Niektórzy lubią rosół z makaronem” („Niektórzy lubią poezję" z tomu Koniec i poczatek, WW s. 289) uwieczniona jest chronicznie niedzielna zupa polska. U Bodegårda jej miejsce zajmuje nietradycyjny "makaronibuljong” (AB s. 21), u Barańczaka i Cavanagh, (B\&C s. 227) i u Trzeciak (JT s. 139, z notacją "chicken-noodle soup”) - kojarząca się z Campbell Soup Company - „chicken noodle soup” (B\&C s. 227). Humorystycznie nieudolna śmierć w wierszu O śmierci bez przesady: „nie zna się na pieczeniu ciasta" (WW s. 320), co w momencie pisania wiersza było w Polsce oczywistą umiejętnością każdej pani domu. U Bodegårda i amerykańskich tłumaczy ten niuans został z konieczności pominięty. Zresztą potrawy w wierszach Szymborskiej są zwykle domowe, proste, tradycyjne i przynależą do rytuału społecznego. Wskazują na „zwykłe” życie, codzienność, akceptowaną prozę życia. Ciasta się dzisiaj na ogół w Szwecji samemu nie piecze, a jeśli już, to z gotowych półproduktów, rytuał zup (obiadów) domowych nie obowiązuje. Zresztą do codzienności przynależą u Szymborskiej także drobne realia PRL-u. Może najbardziej rzucają się w oczy "buty z Chełmka” z wiersza Trema, Ludzie na moście (WW s. 241-242). W Chełmku produkowano buty - powiedzmy - nie najwyższej jakości. „Akcja” wiersza toczy się na wieczorze autorskim, gdzie wystrój sali i oczekiwania są „duchowe, zaś cielesność występującej poetki całkowicie temu przeczy. Stąd skrzypiące buty z Chełmka dodatkowo przeszkadzają w spełnieniu marzeń publiczności. Barańczak, Cavanagh rezygnują z tych nieszczęsnych PRL-owskich butów, zastępując je równie „kompromitującymi” "cut-rate sneakers” (B\&C „Stage Fright”, s.179), Trzeciak tłumaczy to jako "cheap shoes” (JT „Stage Fright” s. 133). Bodegård zachowuje „buty z Chełmka".

Czy w sytuacji zagrożenia, jak w wierszu Szymborskiej, wzywano by w Szwecji, USA czy Włoszech babcię z Zabierzowa? Nie wiem, zgaduję jednak, że w Szwecji długo wahano by się, czy nawet w takiej sytuacji narazić na szwank niezależność rodziców niemowlęcia. 
I tutaj jednak jeszcze nie koniec problemów z tym wezwaniem babci... Szymborska każe ją wezwać „depeszą”. Nie jestem pewny, czy młodszy czytelnik polski jeszcze zna ten wyraz. Kiedy Szymborska pisała ten wiersz, słowo to już brzmiało archaicznie, no... ale nie wiemy, kiedy się akcja wiersza rozgrywa, poetka skacze w nim z epoki na epokę, tworząc świat jako koszmar wszech czasów dla ludzi. W każdym razie depesza (a nie telegram) wskazuje na czas przeszły, choć nie zamierzchły. Barańczak i Cavanagh (B\&C „A Tale Began” s. 210) tak to tłumaczą: „Let's send a cable to grandma in Zabierzów”, co w skojarzeniu z „diplomatic cable" zyskuje dodatkową konotację: informacji poufnej, tajnej, jak w poczcie dyplomatycznej'. Bodegård używa w tłumaczeniu słowa „telegram” („skicka telegram till mormor i Kórnik”, $\mathrm{AB}$ „En påbörjad berättelse" s. $117^{10}$ ). W obu tłumaczeniach znika „wezwanie" babci, zastępuje je eliptyczny skrót: telegram wysyła się po to, żeby - w domyśle - babcia przyjechała. Nie jest to jednak rozwiązanie jednoznaczne: telegram można także wysłać jako powiadomienie. Zresztą w tym wierszu zbudowanym na planie heksametru wtręt aktualny, polityczny brzmiałby chyba fałszywie: to nie mógł być wiersz interwencyjny. I stąd pewnie ta nieco archaiczna „depesza”. Jej następca, telegram, też już dzisiaj domaga się przypisu: dzisiaj wysłano by do babci SMS-a, zatelefonowano by (w PRL-u posiadanie telefonu nie było oczywistością), pewnie z komórki, a może wezwanie miałoby miejsce na Skype'ie.

Jednak nawet na tym nie kończą się problemy... Otóż np. język szwedzki, w przeciwieństwie do angielskiego czy francuskiego, nie ma w swoim repertuarze babci, a babcię przecież trzeba koniecznie wezwać! Szwedzi są tu bardzo konkretni: trzeba się zdecydować, czy chodzi o babcię ze strony matki, czy ojca?! Bodegård wybrał babcię ze strony matki, nie wiem, czy w porozumieniu z Autorką, czy bez, ale innego wyboru raczej nie miał: skoro babcię ulokował w Kórniku, przez co spokrewnił ją z Szymborską, innego wyjścia nie miał. Poza tym babcia ze strony ojca, czyli z perspektywy położnicy teściowa, na mocy działającego w Polsce i Szwecji stereotypu nie bardzo nadawałaby się do magicznej pomocy.

Osobny rozdział należałoby poświęcić temu, co najbardziej lokalne: frazeologizmom i idiomom jako problemowi w przekładzie. W ramach skromnego artykułu nie jest to możliwe. Trzeba jednak zwrócić uwagę na fakt bezsporny: poezja Szymborskiej nasycona jest idiomami i frazeologizmami, na ogół błyskotliwie przez nią przekształcanymi. Wielki sukces tej poezji, dzięki 
ogromnemu wkładowi tłumaczy, do których Szymborska miała szczęście, dowodzi, że przekłady tej poezji, choć trudne i ryzykowne, należą do bardzo udanych. Oznacza to także, że istnieje być może coś takiego, jak wspólnota idiomów i frazeologizmów. Jakie są jej granice - nie wiem. Trzeba by chyba wrócić do zacytowanego na początku Miłosza i powiedzieć, że jesteśmy (byliśmy?) w świecie post-Kartezjańskim, post-Kopernikańskim, post-II-wojny światowej, post doświadczeń totalitaryzmów. Tworzył on pewną wspólnotę świadomości czy sposobów na przetrwanie. Jeśli tak, to część tych doświadczeń kryje się we wspomnianej wspólnocie frazeologizmów i idiomów. Może dzięki temu Szymborska i bliski jej pod tym względem Stanisław Jerzy Lec dają się dobrze tłumaczyć.

Niektóre realia życia codziennego w PRL-u nie są jednak możliwe do przełożenia. „Buty z Chełmka” muszą skrzypieć, co amerykańskim tłumaczom każe ich poszukać w tanich i kiepskich sklepach w USA. Tłumacz szwedzki pozostawiając tę firmę w wierszu, ufał pewnie, że "Chełmek” jest w Szwecji firmą na tyle nieznaną, że - dzięki skrzypieniu produktu - zachowa bylejakość.

Jest jednak miejsce u Szymborskiej, które stanowić może emblemat PRL-u: miejsce zakazu, zawsze przez Szymborską traktowanego z ironią. Jak długo zakazy były w jej wierszach tematyzowane, czytelnicy mogli się do co ich istoty zorientować bez trudu. Co jednak zrobić z tabliczką nierozerwalnie w tamtym świecie związaną z parkami, skwerami i skromnymi kawałkami zieleni w miastach, na której zawsze było napisane: „Nie deptać trawy” (Wielkie to szczęście, Koniec i początek, WW s. 320-321)? W tym wierszu punktem wyjścia jest przekształcony frazeologizm: „nie wiedzieć, w jakim świecie się żyje" w znaczeniu pejoratywnego ulegania naiwnej ułudzie:

Wielkie to szczęście

nie wiedzieć dokładnie,

w jakim świecie się żyje.

[...]

$\mathrm{Z}$ tej perspektywy

$[\ldots]$

napis „Nie deptać trawy”

[byłby] napisem szalonym.

(WW Wielkie to szczęście, s. 320-321)

Barańczak i Cavanagh tłumaczą to tak: 
We're extremely fortunate

not to know precisely

the kind of world we live in.

[...]

From that perspective

[...]

the sign "No walking on the grass"

[whould be] a symptom of lunacy.

(B\&C We're exremely fortunate, s. 258)

Nie wiem, czy napis „No walking on the grass” był wtedy w USA symbolem władzy, ale w tłumaczeniu wzmocnione zostało szaleństwo takiego zakazu w świecie, w którym żyjemy. Ponad podziałami politycznymi. W tym wymiarze, w którym Szymborska najmocniej oddziałuje: w podważaniu oczywistości tego, co oczywiste. Świat Szymborskiej jest właśnie zdumiewająco nieoczywisty, i to się tłumaczom udało wyrazić.

\section{Abstract}

\section{Leonard Neuger}

STOCKHOLM UNIVERSITY

Grandma in Zabierzow: Translating from Local to Local

Neuger explores how local terms in Wisława Szymborska's poetry are translated into English (by Stanisław Barańczak and Clare Cavanagh) and Swedish (Anders Bodegård). Problematic aspects include proper nouns (such as Zabierzów in the poem 'A Tale Begun' or the shoes from Chełmek in 'Stage Fright'), the names of Polish dishes and culinary customs, as well as family relationships (the Swedish translator must decide if the grandma in Zabierzow is a maternal or a paternal grandmother).

\section{Keywords}

translation, proper noun, Wisława Szymborska, Stanisław Barańczak, Clare Cavanagh, Anders Bodegård 